\title{
An Integrated Appraisal of Burgan Reservoir in Soroosh Oil Field, Using Petrographic and Petrophysical Approaches
}

\author{
Davar Ebrahimi' ${ }^{1}$, Abdolhossein Amini2 ${ }^{*}$, Ali Solgi' ${ }^{1}$ Elham Hajikazemi ${ }^{3}$ \\ ${ }^{1}$ Department of Geology, Science and Research Branch, Islamic Azad University, Tehran, Iran \\ ${ }^{2}$ Department of Geology, University of Tehran, Tehran, Iran \\ ${ }^{3}$ Department of Geology Studies, Iranian Offshore Oil Company, Tehran, Iran \\ Email: *ahamini@gmail.com
}

How to cite this paper: Ebrahimi, D., Amini, A., Solgi, A. and Hajikazemi, E. (2016) An Integrated Appraisal of Burgan Reservoir in Soroosh Oil Field, Using Petrographic and Petrophysical Approaches. Open Journal of Geology, 6, 1013-1031. http://dx.doi.org/10.4236/ojg.2016.69076

Received: August 3, 2016

Accepted: September 5, 2016

Published: September 8, 2016

Copyright $\odot 2016$ by authors and Scientific Research Publishing Inc. This work is licensed under the Creative Commons Attribution International License (CC BY 4.0).

http://creativecommons.org/licenses/by/4.0/

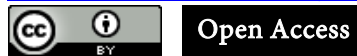

\section{Abstract}

The Burgan Formation in northwest of the Persian Gulf is applied to lower part of Albian age Kazhdumi Formation, where is dominated by coarse to medium terrigenous facies. It is the most susceptible siliciclastic unit in the area to hydrocarbon reservoir. This reservoir is studied in a well of Soroosh oil field with best available data to determine its facies characteristics, sequence stratigraphy and reservoir quality. Based on the petrographic results and log data, 7 facies are determined in the formation, which are mainly composed of sandstone and shale. These facies are classified into three facies associations (FA) based on their sedimentological properties and environmental conditions. The first FA consists of sandstone, siltstone and shale, mostly developed in the lower part of formation, and is related to a fluvial environment. The second FA consists of fluvial sandstones and sandwich by marine shales and is related to fluvial-dominated shallow marine setting (estuary to delta). The third FA consists of limestones of chemical and biochemical origin and is related to a marine condition. According to their reservoir quality, these facies associations show a decreasing trend in porosity and permeability values from FA1 to FA3. The first FA is more abundant in the lower part of the Burgan Formation where causes a good reservoir quality trait. FA2, presenting a medium reservoir quality, is more frequent in the middle parts of studied formation and FA3 is found almost in the upper parts. Based on the results from this study, three 3rd order sequences have been identified. Sequences 1 and 3 are partial but the sequence 2 is the main and most complete one of the formation in the studied area. The paleosol horizons are used for relative sea level change analysis of the formation in sequence stratigraphic studies. 


\section{Keywords}

Burgan Formation, Reservoir Quality, Sequence Stratigraphy, Soroosh Oil Field, Persian Gulf

\section{Introduction}

Terrigenous portion of the Albian sediments (Kazhdumi Formation) in the northwest Persian Gulf is called Burgan Formation (BurgunMbr, in Iran), the name that is derived from Kuwait Stratigraphic Lexicon. This term was first used for that part of the Albian deposits consisting sandstone, shale and oolite ironstone [1]. A thin layer of limestone was later reported in upper part of the formation [2]-[4]. This interval (Burgan Formation) makes significant oil reservoirs in Iraq, Kuwait, Qatar, Saudi Arabia, UAE and Iran [2]. Assessing reservoir quality is important in explorations particularly where sandstones have been exposed to high temperatures and/or high effective stresses for significant periods of geologic time, similar to the situation of the Burgan Formation in Iranian part of the Persian Gulf [5]-[7]. Appraising the reservoir quality of a sandstone reservoir in Iranian part of Persian Gulf using integrated tools can be addressed as the novelty of presented study. This study aims to investigate the facies characteristics, sequence stratigraphy and reservoir properties of this formation in a well (named well $\mathrm{X}$ afterward) with the best available data in Soroosh oil field (Figure 1), and compare the result with other findings on the formation around the Persian Gulf.

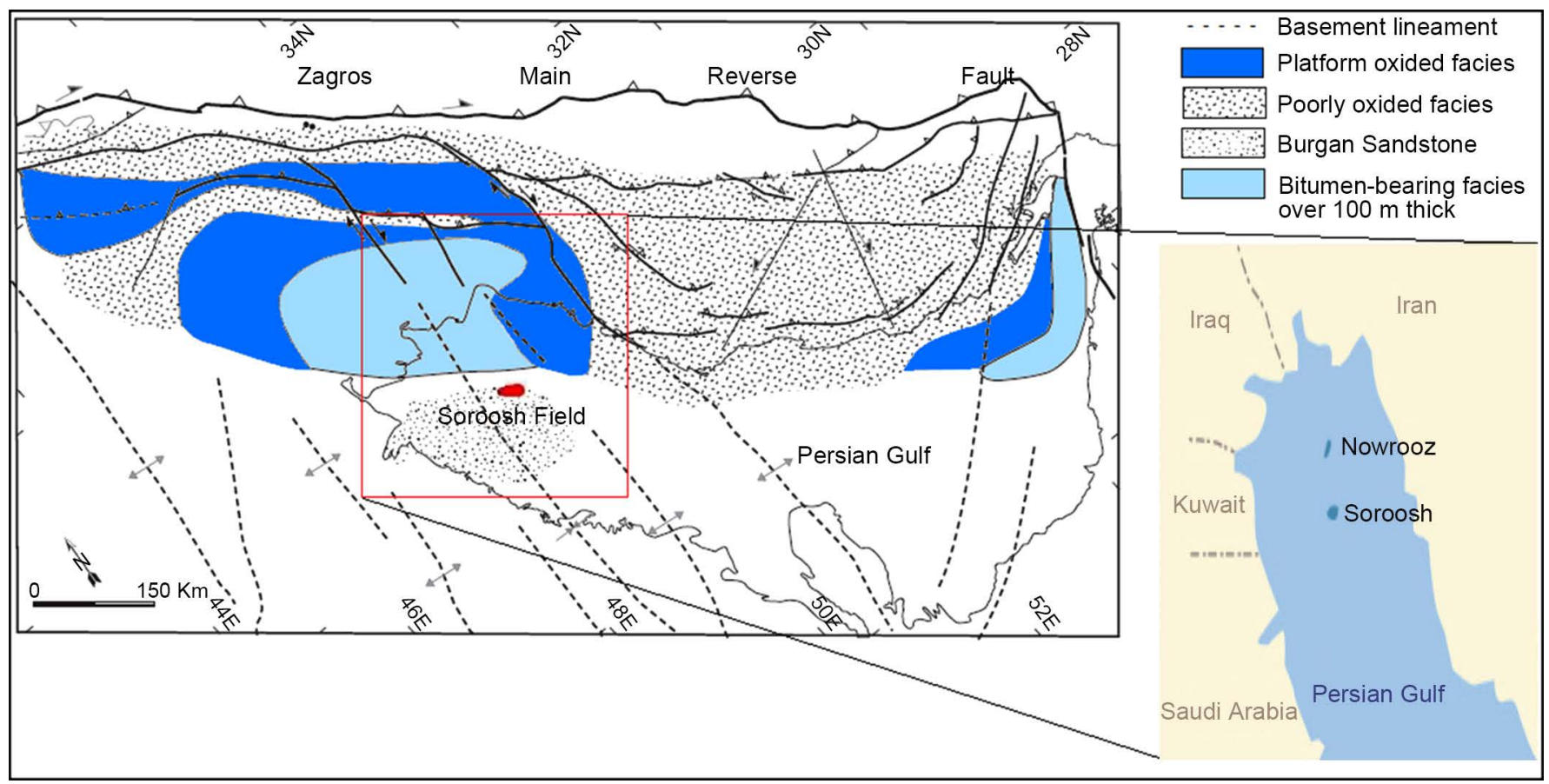

Figure 1. Distribution of major facies of the Kazhdumi Formation in Persian Gulf (modified from 6) and location of the studied field (adapted from 3, 7). 


\section{Methodology}

This study is carried out on $147 \mathrm{~m}$ cores from well X of Soroosh oil field. About 450 thin sections are prepared from the cores for petrographic studies. Detailed description of the cores is used for paleoenvironment analysis. Oil saturation is also taken in to account for petrophysical studies. Both macroscopic and petrographic criteria such as grain size, structures, texture, fossil content, bedding nature, pore types and diagenetic features are used for facies determination. Facies with similar sedimentological characteristics are grouped as facies association fallowing Flugel 2004 [8]. Results from 310 measurements of porosity and permeability on the cores are utilized to assess the reservoir quality of Burgan Formation in the studied field. The reservoir quality of the introduced facies and facies associations are assessed using the porosity and permeability data of the cored samples. Using modified model of Exxon [9]-[12] sequences stratigraphy of the formation is discussed on the basis of its facies characteristics and wireline logs data.

\section{Geological Setting}

The studied field is located about $80 \mathrm{~km}$ west of Kharg Island, in which oil is mainly produced from the Albian Burgan Formation [13]. This formation shows various thicknesses in different parts of the Arabian plate. Its maximum thickness is about 390 $m$ in the east of Kuwait [3]. The studied units are equivalent to lower part of the Kazhdumi Formation in northwest of the Persian Gulf [3] [7] and upper part of Burgan in northern Kuwait [13] [14]. The studied formation (known as Burgan Formation here) is mainly composed of sandstone and shale. The organic matter in the shaley facies is considered terrestrial in origin and related to a coaly environment [15]. Results from rock-eval studies have shown that the shale facies are not reach to the onset of oil generation [15]-[18]. The bitumen-bearing facies is generally confined in the Dezful Embayment by a network of basement faults and partly along the Oman fault, south of Bandar Abbas.

The Burgan Formation occurs on top of the Dariyan (Shuaiba) Formation in the studied area, where is overlain by Dair Formation. Al-Fares et al., 1998 reported the existence of a major hiatus on tap of the Dariyan Formation (Figure 2). Studied formation (Burgan) in northwest of Persian Gulf is a distal equivalent of plant-bearing deltaic sandstones and shales of the Burgan Formation in Kuwait and the NahrUmr Formation in Iraq [3] [19] [20]. In the studied field the Burgan Formation is placed on top of upper Shuaibaclastics. It has been well studied in oil fields of North West of the Persian Gulf, where is informally divided into two parts (Burgan A and B). The Burgan Ain upper part of the formation is dominated by shale and consolidated sandstone. The Burgan B (the reservoir unit) in the lower part of the formation is dominated by fluvial sandstone facies.

\section{Sedimentary Facies}

Facies determination is carried out by the combination of results from core description 
and petrographic studies. Facies analysis of the formation led to documentation of 7 depositional facies which main characteristics are discussed below.

1) Rooted Silty Mudstone (F1)

In the cores it occurs as parallel laminated dark to greyshale with abundant oxidized grains. The plant root remains are clearly recognized on the cores (Figure 3). In

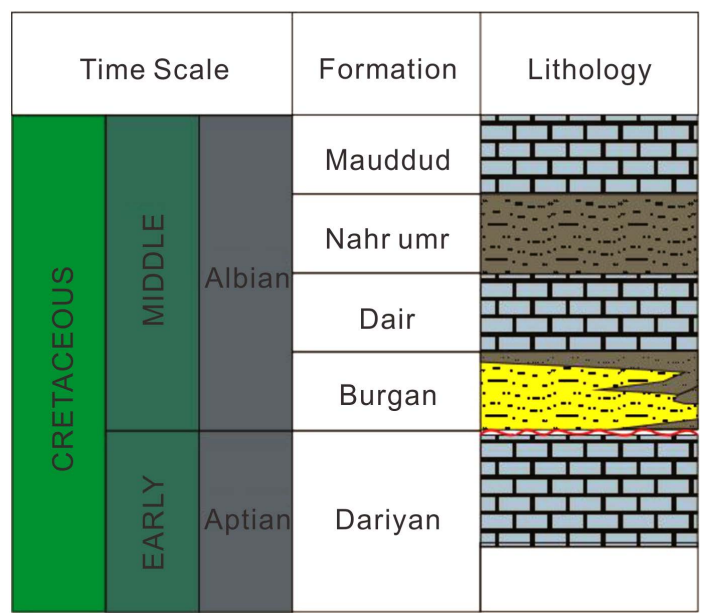

Figure 2. Stratigraphic position of the Burgan Formation among the Early to Mid-Cretaceous sedimentary units of the Western Persian Gulf (modified from 2, 16).
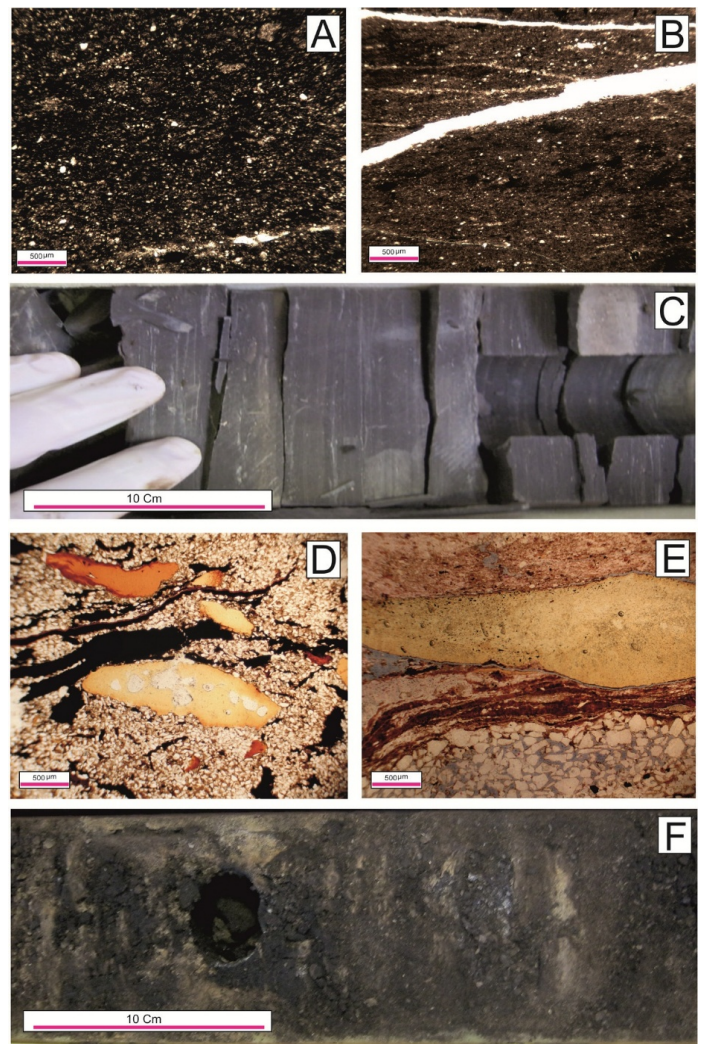

Figure 3. (A) and (B) photomicrograph of Rooted Silty Mudstone. (C) Core image for F1. (D), (E) photomicrograph of Organic rich Quartzarenite. Macroscopic image of F2. 
petrographic studies it is marked by a dark carbonate matrix and scattered silt to sand size quartz grains. Coal relicts are also observed in this facies. This facies is representing a low-energy delta plain setting [21] [22]. Sedimentological characteristics of the facies, abundant root remains and absence of marine fauna indicate its development on a deltal plain.

2) Organic Rich Quartzarenite (F2)

This facies is easily recognizable in the macroscopic study of the cores with its red color. Horizontal bedding is the most important sedimentary structures observed in the study of cores. The most important phenomenon in this facies is the presence of paleosol horizon (Figure 3 and Figure 6) that indicates subaerial exposure for a period of time. Like other facies of the Burgan Formation, this facies is mainly composed of quartz (more than $95 \%$ of the framework). Other grains are chert and opaque minerals. Moderate sorting is seen in quartz grains, but the roundness is weak. Presence of oxidized plant debris is common feature of this facies in the studied thin sections. This facies along with the F1 are observed in the lower parts of the Burgan Formation. This facies is developed in rivers and distributary channels of the delta plain setting [21] [22].

3) Cross-Bedded Quartzarenite (F3)

This facies shows a severe oil staining on the cores (Figure 4). Low cemented sands in the facies show loose and unconsolidated or semi-consolidated nature in the macroscopic studies. The main sedimentary structures are cross-bedding and graded bedding both of which indicate high-energy conditions in the sedimentary environment of this facies (Figure 6). In petrographic studies, this facies is comprised of fine to medium-grained sand size particles most of which are well-sorted quartz. A very small amount of feldspar, plant fragments and chert grains are observed which frequency rarely exceed $5 \%$ of the framework.

This facies is the best reservoir interval of the Burgan Formation, mainly due to the intergranular porosity and lack of cementation. Petrographic studies of the facies indicate limited cementation so a loose/semi-consolidated nature of the facies. Poor cementation of the facies is probably due to the abundant input of clastic sediments. Moreover, the release of methane gas could result in deposition of unconsolidated sandstone [23]. Living conditions were not suitable for organisms due to high energy condition, changes in salinity, and presence of turbulent currents [24]. Bioturbation is rare in such a condition [24].

Presence of high flow regime sedimentary structures, scarcity of fossil content and trace fossils, well sorting and roundness of the framework grains, and texturally and mineralogically nature indicate mouth bars of feeding channels for its depositional environment [25]-[28].

Although the sediment load entering to the basin was transferred by fluvial channels, the sedimentation is influenced by the tides, in such a way that evidences of land such as plant fragmentation cannot be seen in this facies. Moreover, the clay particles that might have entered the depositional environment along with the sediment load are re 

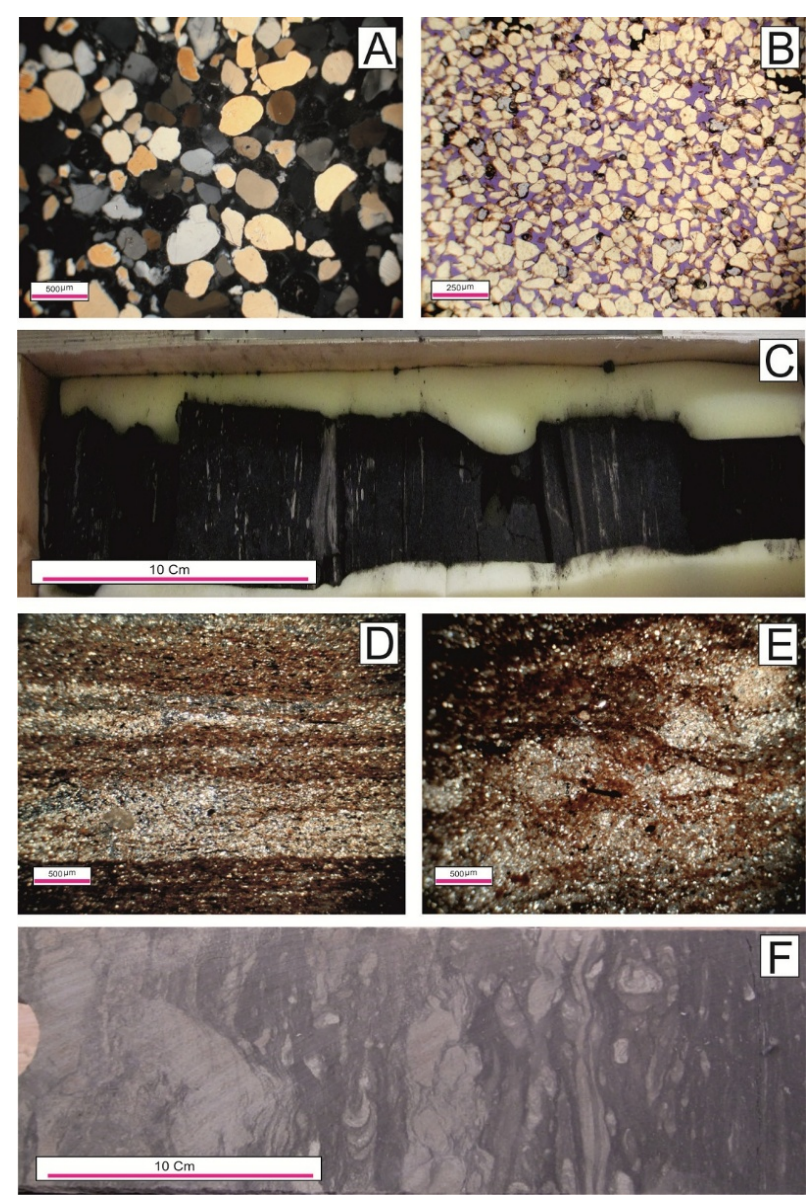

Figure 4. Photomicrograph of facies F4 (quartzarenite) representing its unconsolidated to semi-consolidated nature ((A), (B)) and horizontal burrows ((D), (E)). Core images from the F4 showing the cross-bedding structure and dense bioturbation.

moved by the high energy in this environment. Based on these results and the comparison with other studies, its sedimentary environment is considered as Delta bar or Mouth bar [25]-[28]. This reservoir facies has been reported in equivalent deposits of Kuwait [14] [29] and south/southwest Iran [4].

4) Bioturbated Fine Sandstone (F4)

This facies is a bioturbated fine-grained sandstone with gray to green color and parallel lamination. Horizontal burrows are the most important phenomena that are observed in the cores (Figure 4). The Asterosoma ichnofossil are detectable in some cores (Figure 6). The framework of this facies is composed of fine sand size quartz grains with some marine fauna and glauconite. Oxidant particles are absent and small amber pieces are rarely observed (Figure 4). In some samples of the facies, signs of carbonate and siderite cement are observed.

Considering the described features this facies is related to distal delta channels [27] [28]. Bioturbation in the facies is attributed to organisms' activities in the sediments. These activities were more common in the marine part of channels/mouth bars [30]. Presence of Asterosoma, a marine ichnofacies, in this facies strongly supports such an 
indication (cf. [24]).

5) Oolitic Ironstone (F5)

This facies is composed of dark green to brown terrigenous nodules with oolitic fabric. It shows different features from other facies of the formation (high density an oolitic fabric) by which it is easily recognized in the core studies. It shows some turbidity structures which may seems to be the result of organisms activity or water escape (Figure 5). The ooids are mostly siderite in composition (Figure 6) with minor hematite. The matrix, mostly carbonate with scattered $(<5 \%)$ silt size quartz grains (Figure 5$)$, is dark brown to red in color.

This facies is observed in the upper part of the Burgan Formation where is in alternation with mudstone and siltstone facies (F4 and F6). F5 is related to post-oxic to anoxic conditions below fair-weather wave base (FWWB) and above storm-weather wave base (SWB) with periodic storms. Similar facie is reported from estuarine sub-environment [31]. This facies seems to be associated with the relative sea level risein the studied succession. This facies is not reported in the Burgan Formation in Arabian plate.
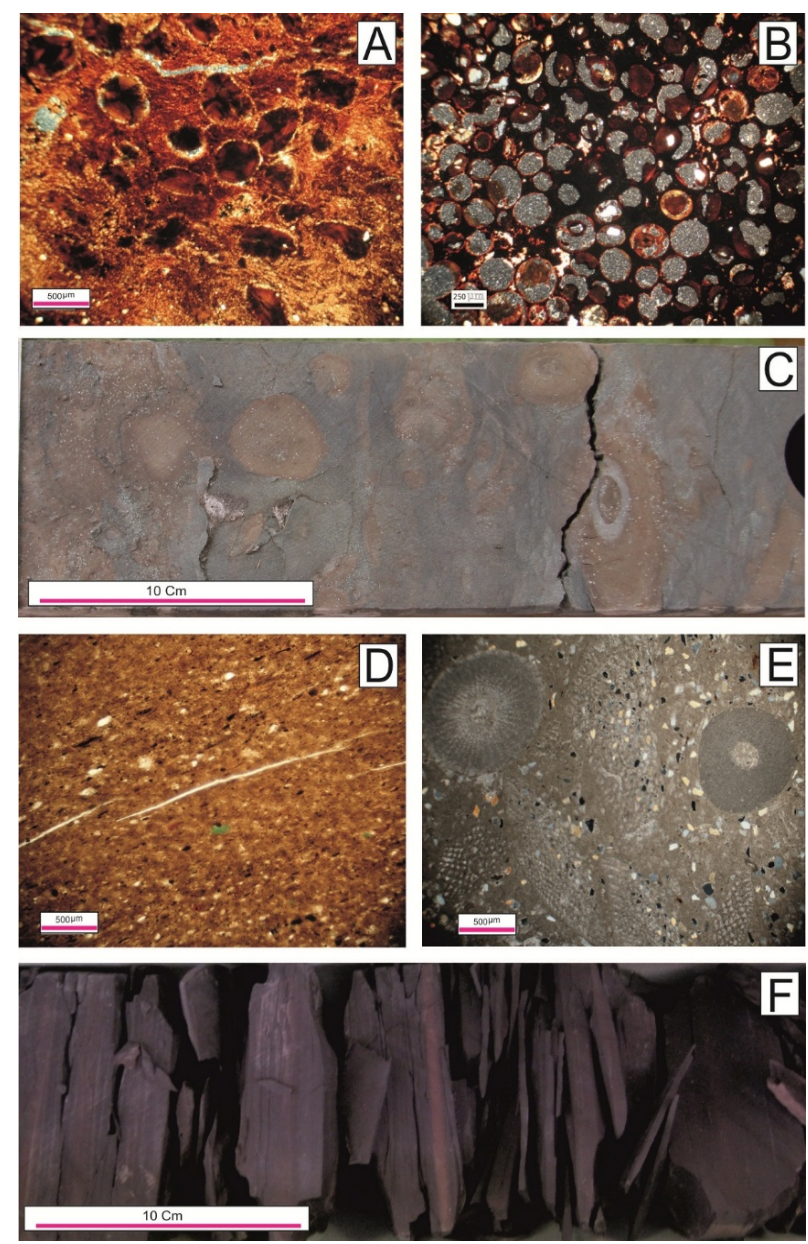

Figure 5. Representative photomicrograph of facies F5, Oolitic Ironstone ((A) \& (B)), facies F6, fine laminated mudstone, (D). and facies F7, orbitolina bioclast packstone (E). Core images of the facies F5 (C), and F6 (F). 

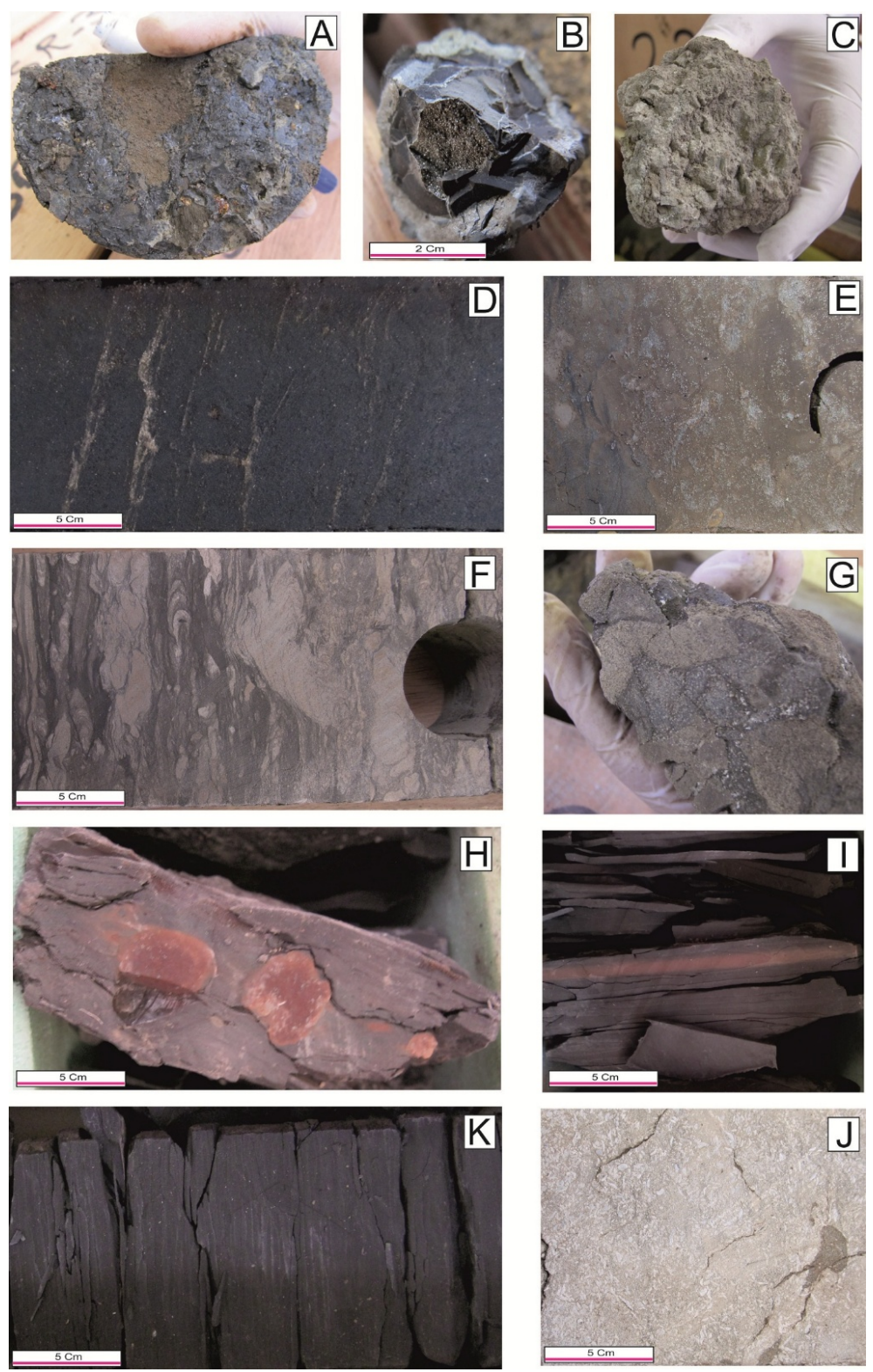

Figure 6. (A) Coal remains in F1. (B) Amber in F2. (C) Paleosol in F2. (D) Cross-bedding in F3. (E) Oolitic fabric. F: Assemblage of bioturbation in F4. (G) Soft-sediment deformation structures in F4. (H) \& (I) Nodule and band siderite in F6. K: Fine lamination in F6. (J) Echinoderm and Orbitolina remains in F7.

\section{6) Fine Laminated Mudstone (F6)}

This facies is a fine laminated mudstone, easily recognized from the adjacent facies on the cores by its clear lamination, fissility and dark color (organic rich) (Figure 5). Alternation of silt and clay is the main cause of laminations throughout the facies. Siderite nodules and bands are distinct in the cores (Figure 6). The facies gradually changes to F5 (oolitic Ironstone) or F7 (sandy orbitolina packstone) upward, while shows a sharp contact with the underlying sandstones (F4). The sharp contact seems to be the 
result of marine erosion, removal of some muddy/shaley units. Fossils are not common in this facies, similar to other facies of the formation, although some remains of echinoderms and foraminiferas are observed. Pyrite and glauconite are locally observed in this facies (Figure 5). Similar facies are reported in the formation in Arabian Plate and south/ southwest Iran (e.g. [3] [4] [14] [29]).

7) Orbitolina Bioclast Sandy Packstone (F7)

It is the only limestone facies in the Burgan Formation that is quite distinct from others in the core studies. It is a cream limestone with scattered white echinoderm and orbitolina fossils and regular fracturing (Figure 6). This facies is more common in the lower part of the formation. In petrographic studies it shows a packstone to wackestone nature with echinoderm and orbitolina allochems (Figure 5). In some samples the amount of terrigenous quartz is significant, that provides a mixed silisiclastic-carbonate nature to the facies. Based on the sedimentological characteristics and fossil content, while compared with the standard microfacies of Flugel 2004, this facies is related to the open marine environment of a carbonate system which was periodically influenced by siliciclastic input [8] [32]-[34]. This facies indicates deepest condition in sedimentary environment of the Burgan Formation, so considered as a good marker for detection of the maximum flooding surface in sequence stratigraphic analysis. This key layer has not been reported in most previous studies, and a marine mudstone is identified instead (e.g. [14]).

\section{Facies Associations}

The studied facies are classified into 3 facies associations (genetically related facies) that represent 3 sub-environments in depositional setting of the Burgan Formation.

1) Facies Association 1 (FA1)

This facies association is characterized by dominance of fluvial-related deposits (F1 and F2) including thick units of sands with thin inter beds of siltstone and shale. The FA1 is marked by abundance cross-bedding, well sorting of the facies, and oxidized particles and paleosol horizons. The fluvial-related processes seem responsible for development of this facies association, although marine processes such as waves and tides were insignificantly involved. This facies association is much more frequent in the lower parts of the Burgan Formation. The porosity value reaches up to $40 \%$ in some parts of this facies association. In core studies, maximum oil staining of the formation is seen in this FA, where unconsolidated sands are common. This FA is located in the lower parts of the Burgan Formation (its thickness is about 60 meters), where the best reservoir horizons of the formation are observed.

2) Facies association 2 (FA2)

This facies association is composed of F3 and F4 deposited in the delta front zone. F3 is deposited in the mouth bar of delta front (a zone which river meets the sea) and its cross bedding and high sorthing is also derived from the high energy level of this position. The sedimentary constituent composing this facies are mainly delivered by rivers, 
while marine processes (like waves) dominated the distribution and deposition of them. The F4 is deposited in the seaward part of the delta front (to address it more clearly, in the lower parts of the delta slop) and fine sandstone presenting intense bioturbation is its major component.

3) Facies association 3 (FA3)

This facie association is composed of facies involving fine particles and lamination. The FA3 is marked by sedimentary features that are related to deepest part of the depositional environment. Presence of glauconite, pyrite, and organic-rich facies (dark/grey color) indicate a reducing condition during its development. This facies association has low porosity and permeability values and showsno oil staining in core studies (Figure 7).

The most important characteristics of the facies associations including lithology, depositional environment, sedimentary structures, texture and grain size, porosity and permeability values, and their position in the studied succession are illustrated in Figure 7.

\section{Depositional Environment}

Results from facies analysis of the Burgan Formation, along with those from its equivalent units in Arabian plate [2] [4] [14] [29] indicate a shallow marine lobate shoreline (delta) for its depositional environment (Figure 8). The facies in lower part of the formation, (sand-dominated) are related to the deltaplain sub-environment. These facies are highly influenced by marine processes and the relative sea levels change. Development of the estuary facies in this part of the environment is the result of such processes.

The delta was most likely developed in the north margin of Arabian Plate. The distributary channels on the delta plain had a northeast trend carrying detritus to the deeper parts of the basin. The channel fill facies of this sub-environment (FA1) provide best hydrocarbon prolific sandy units.

Relative sea level change seems to be responsible for changing this condition to transitional (FA2) then marine settings (FA3). Development of thin sandy units sandwiched within the shaley facies (FA2) and organic-rich shales with minerals of reduction conditions (FA3) are the result of such a relative sea level rise (Figure 7 and Figure 8).

\section{Reservoir Quality}

Reservoir quality of the studied facies is discussed by measurements of their porosity and permeability values on the cores. In this regard the Burgan Formation can be divided into two distinct zones (good and poor reservoir zones).Results from petrophysical analysis of the facies show that the F1, F2 and F3 have good reservoir potential (Figure 9). The average porosity of these facies are $29 \%, 29.17 \%$ and $30.81 \%$ respectively. The average permeability values for the F1, F2, and F3 is measured $4200 \mathrm{mD}$, 5459 and $10377 \mathrm{mD}$, respectively.

Reservoir quality of other facies (F4 to F7) occur in lower range with a decreasing 


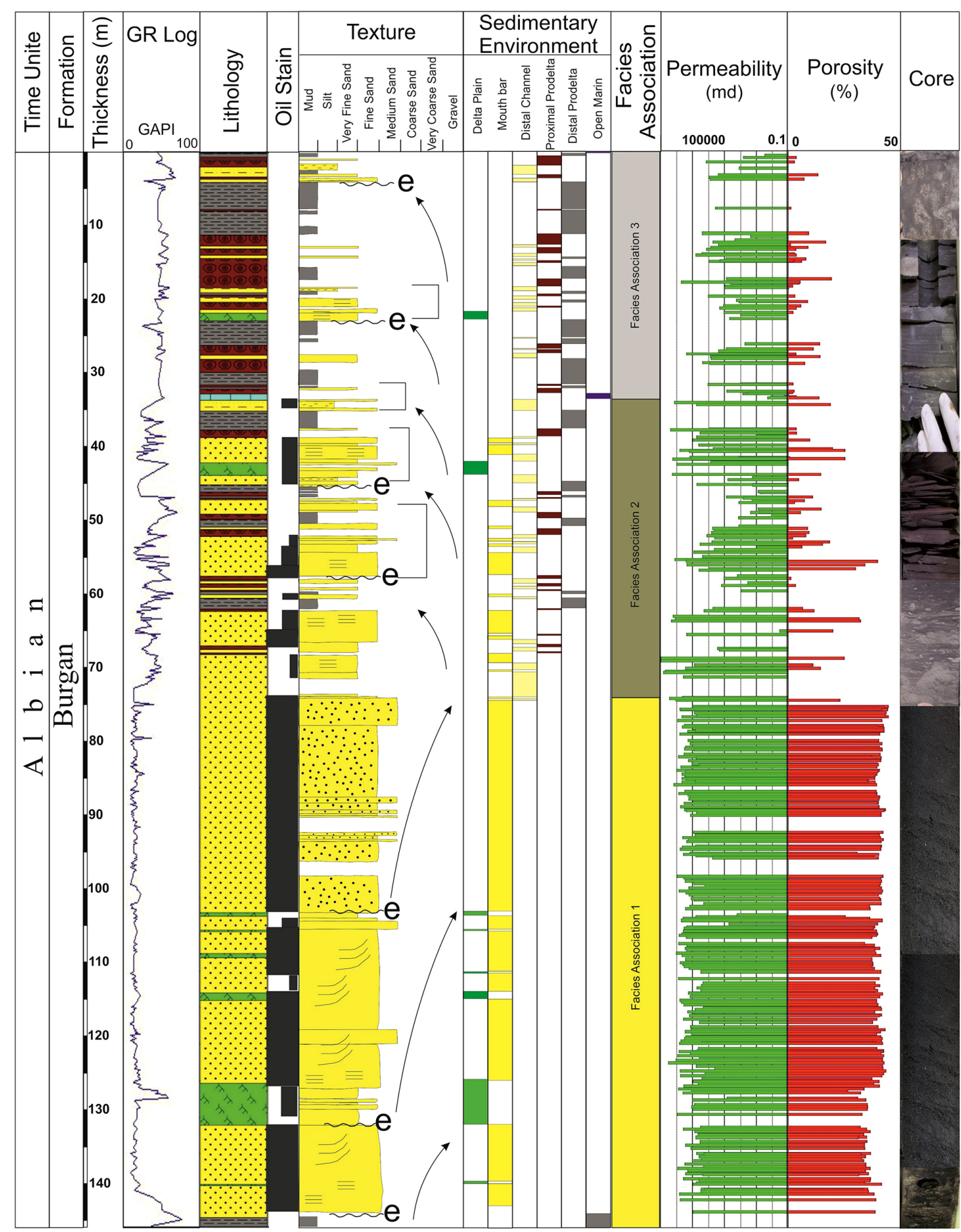

\begin{tabular}{|l|l|l|}
\hline \multicolumn{2}{|c|}{ Lithology } & \multicolumn{2}{c|}{ Sedimentary Structures } \\
\hline Limestone & Silty Sandstone & \\
\hline Shale & Sandstone & Channel \\
\hline Ooid Ironstone & Organich rich Sandstone & $\because \because \vdots$ Loss Sand \\
\hline
\end{tabular}

Figure 7. Constituent facies, and facies associations of the studied formation, and their related depositional environments and petrophysical characteristics. 


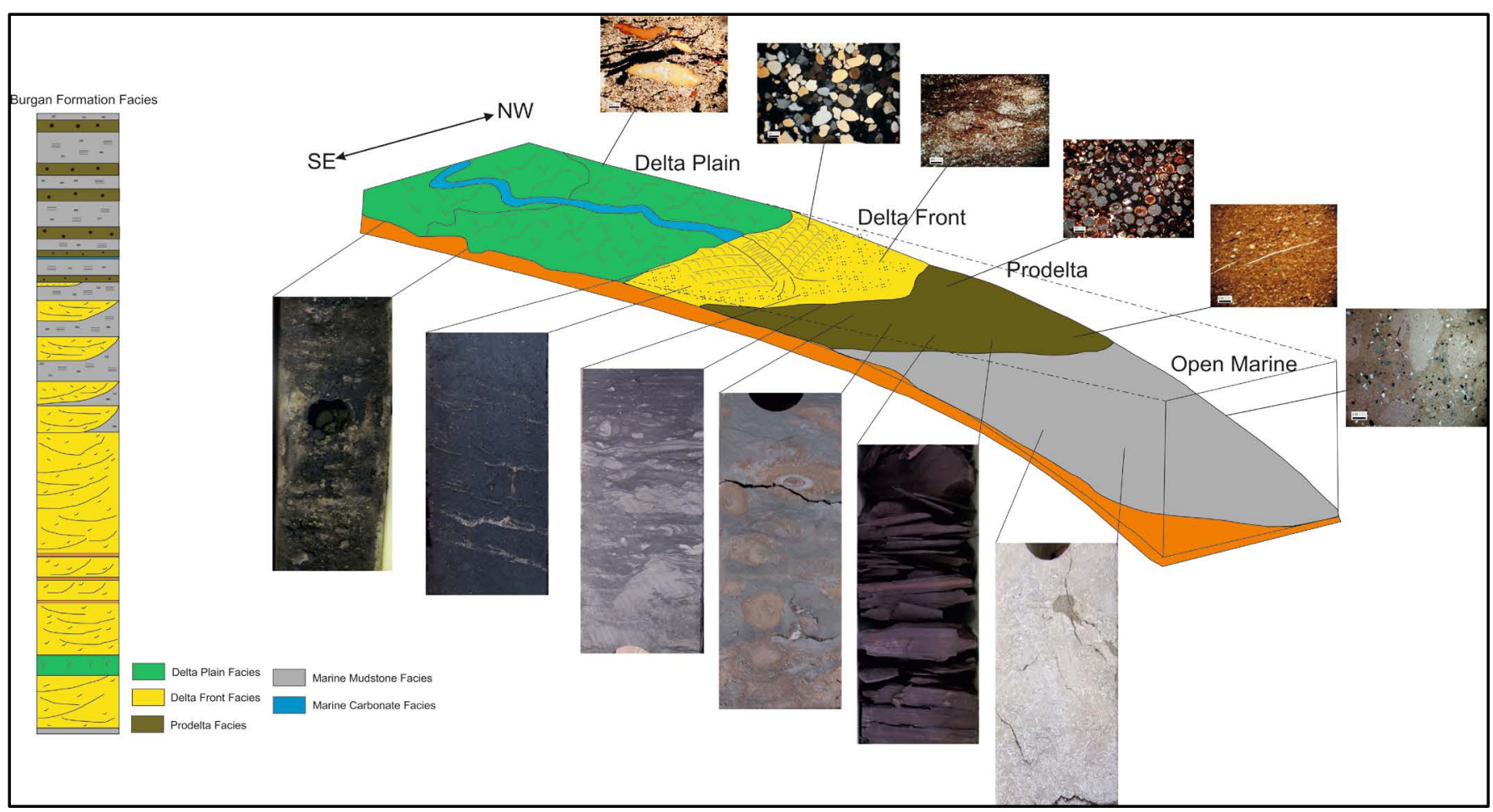

Figure 8. Schematic diagram representing depositional environment of the Burgan Formation in the studied field.

trend from F4 to F7 (Figure 9). The average porosity values in F4 and F5 is measured 7 and $19.5 \%$, respectively. Their permeability averages are also 36.7 and $7.4 \mathrm{mD}$, respectively. Based on the permeability values, reservoir quality of F4 is better than that of F5, although the porosity value is different. The average porosity is for F6 is $21 \%$, while its permeability average is $7.2 \mathrm{mD}$ that indicates a non-reservoir unit. Micropores are frequent in this facies. In F7, The average values of porosity and permeability in facies F7 are determined as $7 \%$ and $7 \mathrm{mD}$, respectively.

From reservoir quality point of view, the Burgan Formation in the studied field can be divided in to three zones. Lower part of the formation (sand-dominated facies or FA1) as a zone with good, middle part of the formation (alternation of sand and mud or FA2), as a zone with moderate and upper part of the formation (shale dominated facies or FA3) as poor quality zones (Figure 10). In this regard reservoir quality of the formation has a decreasing trend form base to top (Figure 9). After appraising this formation in the present study, it is clear that there is a notable categorization of the Burgan Formation in three zones: the lower, middle and upper. Lower part of the formation (sand-dominated facies or FA1) as a zone with good, middle part of the formation (alternation of sand and mud or FA2), as a zone with moderate and upper part of the formation (shale dominated facies or FA3) as poor quality zones.

Correspondence of the reservoir zones of the formation to its facies association indicates the greater role of depositional environment, than diagenesis, in the reservoir quality (Figure 9 and Figure 10). Generally speaking, sandstone reservoir are much more resistant to diagenesis in comparison with carbonate ones. In Burgan reservoir, limited di 

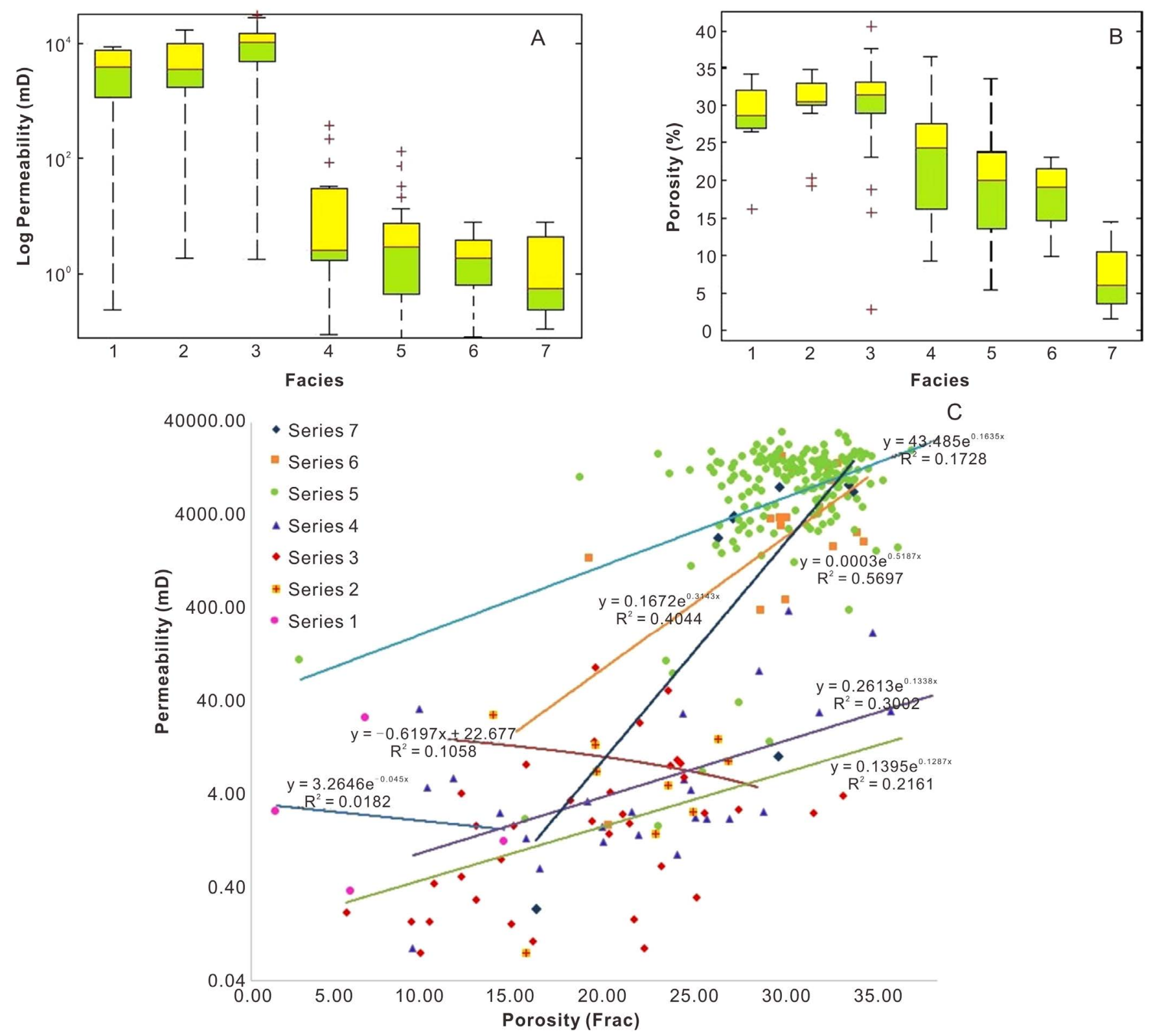

Figure 9. Box plot (A) and Whisker plot (B) representing the permeability and porosity values of the studied facies. Porosity-permeability cross-plot of the studied facies (C) showing the highest reservoir quality in F1, F2 and F3. Decrease of reservoir quality from F4 to F7.

agenetic factors with a negligible influence on reservoir quality are observed. Another issue is an almost high regression between porosity and permeability for all facies. This confirms that earlier environment controls the values of these two important parameters.

\section{Sequence Stratigraphy}

The Albian siliciclastic sediments of the Arabian Plate are considered as lower part of the Wasia Sequence in the Cretaceous stratigraphic record [3] [14]. These siliciclastic sediments include Burgan, Kazhdumi, Nahrumr, Safaniya, and Khafij formations where 


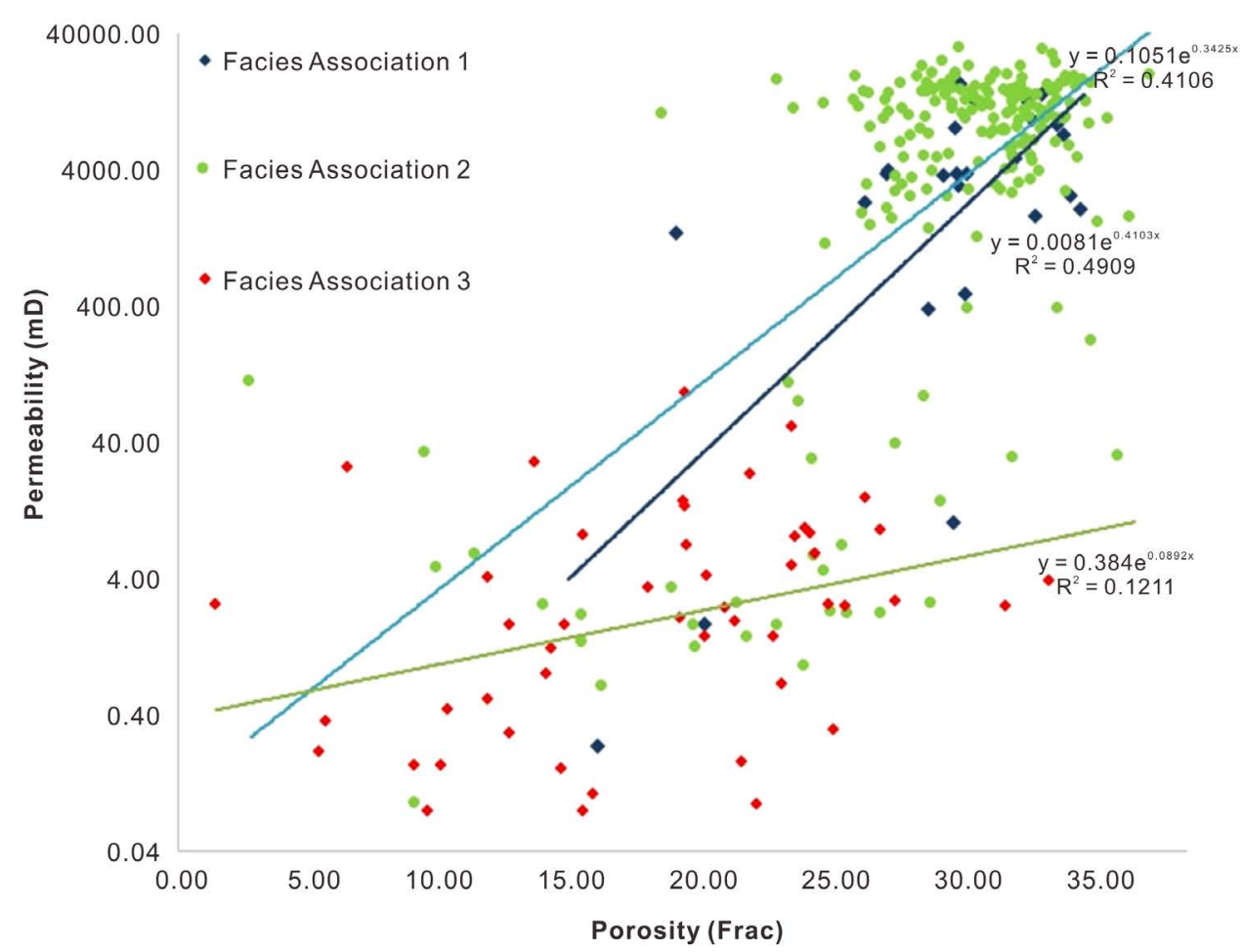

Figure 10. Porosity and permeability values of the 3 determined facies associations of the studied formation.

fallowed by carbonate successions of Maddud, Mishrif, and Sarvak formations [14]. The Burgan Formation with a fining up (deepening) trend can be considered as transgressive systems tracts of the Wasia Sequence. In this large scale systems tract, some small scale sequences and stratal surfaces can be determined based on their genetic relationship andthe nature of their bounding surfaces [12].

Using the modified Exxon model [9]-[12], three sequences are distinguished in the studied field (Figure 11). Considering the available data, the main emphasis is taken on the facies characteristics in the sequence stratigraphic studies.

\subsection{Sequence 1}

This sequence is located in the lower part of the formation and is composed of a HST by a type one sequence boundary (SB1) above. It is about $15 \mathrm{~m}$ thick where is marked by a distinct erosional surface at base (contact between Dariyan and Burgan formations) and a paleosol horizon on top. The lower part of this sequence seems to be eroded away, leaving a composite stratal surface here (MFS and SB). This erosion seems responsible for eradicating the TST of sequence 1 . This sequence is dominated by sandy facies which show good reservoir quality.

\subsection{Sequence 2}

This is the main and most complete sequence of the Burgan Formation in the studied 


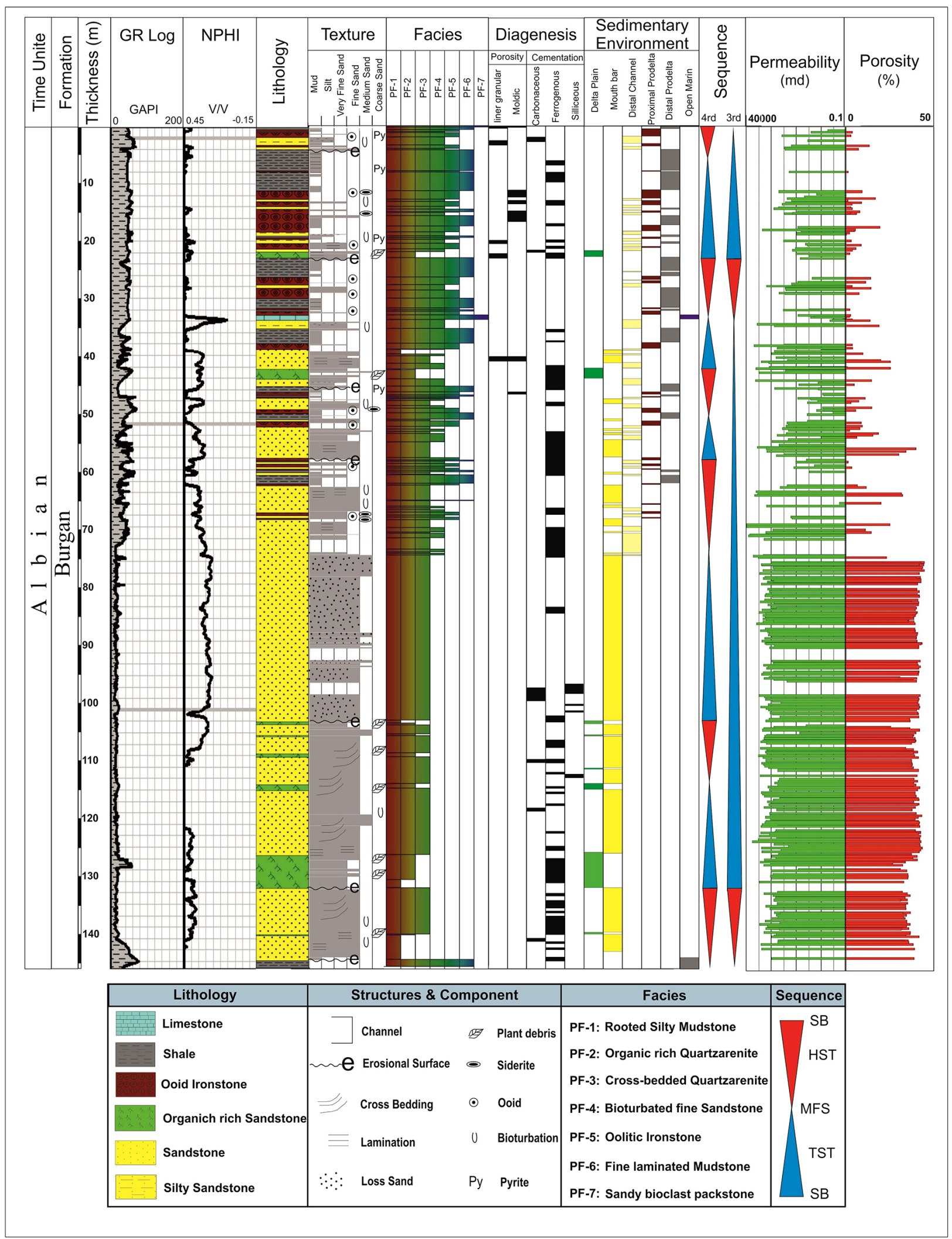

Figure 11. A sedimentological log representing the constituent facies, their depositional environment and determined sequences of the studied formation. 
area. Its lower surface is a type one sequence boundary (palaeosol) while its upper boundary is determined by channel filled facies with abundant plant remains. The MFS is in this sequence is distinguished by occurrence of the limestone key bed (F7). A sharp peak in neutron porosity wireline log (NPHI) is also another evidence for distinction of the MFS. This limestone layer, about $1 \mathrm{~m}$ thick, is used for such a purpose in some other parts of the Arabian Plate [14]. This sequence is dominated by sandy facies (mostly unconsolidated) in the lower ironstone facies in the upper parts. A decreasing trend in the reservoir quality of the sequence is well understood from its facies distribution.

\subsection{Sequence 3}

Similar to the sequence 1, this is a partial sequence in which only the TST is observed. The lower boundary of this sequence is determined by erosional surfaces and channel-filled facies. The sequence is mostly composed of shale (F6), ironstone (F5) and bioturbated sandstone (F4), with total thickness of about $23 \mathrm{~m}$. This sequence occurs in the upper part of the formation, where changes to Dair Limestone upward. This sequence shows the least reservoir quality in the studied succession.

\section{Conclusions}

Integration of results from core data, thin sections prepared from the cores, and logs led to determination of constituent facies of the formation. Classifying the facies into genetically related packages, 3 facies associations are determined. On the basis of facies and facies associations' characteristics, a delta setting with 3 main sub-environments is determined as depositional environment of the formation. In general, the constituent facies of the formation show a deepening up trend, indicative of relative sea level rise during their development.

In terms of reservoir quality, the constituent facies are divided into three zones (good, moderate and poor) which are matched with the determined facies associations and their related depositional setting. Such a correlation indicates significant role of depositional environment in reservoir quality of the formation. Such a result is also indicative from decreasing trend of reservoir quality form base to top.

Three sequences are also attributed to Burgan Formation in this study regarding its cores, thin sections and wireline logs.

\section{Acknowledgements}

The authors wish to thank and gratitude Iranian Offshore Oil Company (IOOC) for providing us required data and all facilities. We are also grateful to Mr. Bijan Noori for his guidance throughout this project.

\section{References}

[1] Owen, R.M.S. and Nasr, S.N. (1958) Stratigraphy of the Kuwait-Basra Area. In Weeks, L.G., 
Ed., Habitat of Oil, AAPG, Memoir 1, 1252-1278.

[2] Alsharhan, A.S. (1994) Albianclastics in the Western Arabian Gulf Region: A Sedimentological and Petroleum-Geological Interpretation. Journal of Petroleum Geology, 17, 279300. http://dx.doi.org/10.1111/j.1747-5457.1994.tb00135.x

[3] Alsharhan, A.S. and Nairn, A.E.M. (1997) Sedimentary Basins and Petroleum Geology of the Middle East. Elsevier, Netherlands.

[4] Van Buchem, F.S.P., Baghbani, D., Bulot, L.G., Caron, M., Gaumet, F., Hosseini, S.A., Keyvani, F., Schroeder, R., Swennen, R., Vedrenne V. and Vincent, B. (2010) Barremian-Lower Albian Sequence-Stratigraphy of Southwest Iran (Gadvan, Dariyan and Kazhdumi Formations) and Its Comparison with Oman, Qatar and the United Arab Emirates. GeoArabia Special Publication, 4, 503-548.

[5] Taylor, T.R., Giles, M.R., Hathon, L.A., Diggs, T.N., Braunsdorf, N.R., Birbiglia, G.V. and Espejo, I.S. (2010) Sandstone Diagenesis and Reservoir Quality Prediction: Models, Myths, and Reality. AAPG Bulletin, 94, 1093-1132. http://dx.doi.org/10.1306/04211009123

[6] Bahroudi, A. and Talbot, C.J. (2003) The Configuration of the Basement beneath the Zagros Basin. Journal of Petroleum Geology, 26, 257-282.

http://dx.doi.org/10.1111/j.1747-5457.2003.tb00030.x

[7] Bordenave, M.L. and Burwood, R. (1990) Source Rock Distribution and Maturation in the Zagros Belt; Provenance of the Asmari and Bangestan Reservoir Oil Accumulations. Organic Geochemistry, 16, 369-387. http://dx.doi.org/10.1016/0146-6380(90)90055-5

[8] Flügel, E. (2004) Microfacies of Carbonate Rocks. Springer, Berlin Heidelberg. http://dx.doi.org/10.1007/978-3-662-08726-8

[9] Catuneanu, O., Galloway, W.E., Kendall, C.G.St.C., Miall, A.D., Posamentier, H.W., Strasser, A. and Tucker, M.E. (2011) Sequence Stratigraphy: Methodology and Nomenclature. Newsletters on Stratigraphy, 44, 173-245. http://dx.doi.org/10.1127/0078-0421/2011/0011

[10] Embry, A.F. (2009) Practical Sequence Stratigraphy. Canadian Society of Petroleum Geologists, Canada.

[11] Hunt, D. and Tucker, M.E. (1992) Standard Parasequences and the Forced Regressive Wedge System Tract; Deposition during Base Level Fall. Sedimentary Geology, 81, 1-9. http://dx.doi.org/10.1016/0037-0738(92)90052-S

[12] Catuneanu, O. (2006) Principles of Sequence Stratigraphy. Elsevier, Amsterdam, 375 p.

[13] Motiei, H. (1993) Stratigraphy of Zagros. In: Hushmandzadeh, A., Ed., Treatise on the Geology of Iran, Geological Survey of Iran Press, Tehran.

[14] Strohmenger, C.J., Patterson, P.E., Al-Sahlan, G., Mitchell, J.C., Feldman, H.R., Demko, T.M., Wellner, R.W., Lehmann, P.J., McCrimmon, G.G., Broomhall, R.W. and Al-Ajmi, N. (2006) Sequence Stratigraphy and Reservoir Architecture of the Burgan and Mauddud Formations (Lower Cretaceous), Kuwait. In: Harris, P.M. and Weber, L.J., Eds., Giant Hydrocarbon Reservoirs of the World: From Rocks to Reservoir Characterization and Modeling, AAPG Memoir 88/SEPM Special Publication, 213-245.

[15] Kamali, M.R., Bashari, A., Sobhi, G. and Mahmoudian, H. (2012) Distribution and Type of Organic Matter in Cretaceous to Tertiary Source Rocks in Soroosh and Nowrooz Fields, Persian Gulf. Geopersia, 2, 13-25.

[16] Bashari, A. (2008) Thermal History Reconstruction in the Soroosh and the Nowrooz Field, the Persian Gulf, Based on Apatite Fission Track Analysis and Vitrinite Reflection Data. Journal of Petroleum Geology, 31, 153-165. 
http://dx.doi.org/10.1111/j.1747-5457.2008.00413.x

[17] Ghazban, F. (2007) Petroleum Geology of the Persian Gulf. Tehran University and National Iranian Oil Company Publications, Tehran.

[18] Sefidari, E., Amini, A. and Dashti, A. (2015) Source Rock Characteristics of Albian Kazhdumi Formation in Zagros Region. Arabian Journal of Geosciences, 8, 8327-8345. http://dx.doi.org/10.1007/s12517-015-1782-y

[19] Ibrahim, M.I.A. and Al-Hitmi, H.H.A. (2000) Albian-Cenomanian Palynology, Paleoecology and Organic Thermal Maturity of Well DK-B in the Dukhan Oil Field of Western Qatar. GeoArabia, 5, 483-508.

[20] Alavi, M. (2004) Regional Stratigraphy of the Zagros Fold-Thrust Belt of Iran and Its Proforeland Evolution. American Journal of Science, 304, 1-20. http://dx.doi.org/10.2475/ajs.304.1.1

[21] Retallack, G.J. (2001) Soils of the Past: An Introduction to Paleopedology. Blackwell Scientific Publication, Oxford. http://dx.doi.org/10.1002/9780470698716

[22] Bhattacharya, J.P. (2003) Deltas and Estuaries, In: Middleton, G.V., Ed., Encyclopedia of Sedimentology, Kluwer Academic, Boston, 310-322.

http://dx.doi.org/10.1007/978-1-4020-3609-5_62

[23] Reading, H.G. and Collinson, J.D. (1996) Clastic Coasts. In: Reading, H.G. Ed., Sedimentary Environments: Process, Facies and Stratigraphy, Blackwells, Cornwall, 154-231.

[24] Gingras, M.K., MacEachern, J.A. and Dashtgard, S.E. (2011) Process Ichnology and the Elucidation of Physico-Chemical Stress. Sedimentary Geology, 237, 115-134. http://dx.doi.org/10.1016/j.sedgeo.2011.02.006

[25] Coleman, J.M. and Prior, D.B. (1982) Deltaic Environments. In: Scholle, P.A. and Spearing, D.R., Eds., Sandstone Depositional Environments, Vol. 31, AAPG Memoir, 139-178.

[26] Ito, M., O’Connell, S., Stefani, A. and Borella, P. (1992) Fluviodeltaic Succession at the Wombat Plateau: Upper Triassic Siliciclastic-Carbonate Cycles. Proceedings of the Ocean Drilling Program, 122, 109-128. http://dx.doi.org/10.2973/odp.proc.sr.122.139.1992

[27] Buatois, L.A., Santiago, N., Parra, K. and Steel, R. (2008) Animal-Substrate Interactions in an Early Miocene Wave-Dominated Tropical Delta: Delineating Environmental Stresses and Depositional Dynamics (Tacata Field, Eastern Venezuela). Sedimentary Geology, 78, 458-479. http://dx.doi.org/10.2110/jsr.2008.053

[28] Morad, S., Al-Ramadan, K., Ketzer, J.M. and De Ros, L.F. (2010) The Impact of Diagenesis on the Heterogeneity of Sandstone Reservoirs: A Review of the Role of Depositional Facies and Sequence Stratigraphy. AAPG Bulletin, 94, 1267-1309.

http://dx.doi.org/10.1306/04211009178

[29] Al-Eidan, A.J., Wethington, W.B. and Davies, R.B. (2001) Upper Burgan Reservoir Distribution, Northern Kuwait: Impact on Reservoir Development. GeoArabia, 6, 179-208.

[30] Coleman, J.M. and Prior, D.B. (1980) Deltaic Sand Bodies. Short Course Education Course Note Series, AAPG, 5.

[31] Taylor, K.G., Simo, J.A., Yocum, D. and Leckie, D.A. (2002) Stratigraphic Significance of Ooidal Ironstones from the Cretaceous Western Interior Seaway: The Peace River Formation, Alberta, Canada, and the Castlegate Sandstone, Utah, USA. Journal of Sedimentary Research, 72, 316-327. http://dx.doi.org/10.1306/060801720316

[32] Pomar, L.W.C. (2001) Types of Carbonate Platform: A Genetic Approach. Basin Research, 13, 313-334. http://dx.doi.org/10.1046/j.0950-091x.2001.00152.x 
[33] Wilson, B.R. (1975) Carbonate Facies in Geological History. Springer, Berlin. http://dx.doi.org/10.1007/978-1-4612-6383-8

[34] Al-Fares, A.A., Bouman, M. and Jeans, P. (1998) A New Look at the Middle to Lower Cretaceous Stratigraphy, Offshore Kuwait. GeoArabia, 3, 543-560.

Submit or recommend next manuscript to SCIRP and we will provide best service for you:

Accepting pre-submission inquiries through Email, Facebook, LinkedIn, Twitter, etc. A wide selection of journals (inclusive of 9 subjects, more than 200 journals)

Providing 24-hour high-quality service

User-friendly online submission system

Fair and swift peer-review system

Efficient typesetting and proofreading procedure

Display of the result of downloads and visits, as well as the number of cited articles Maximum dissemination of your research work

Submit your manuscript at: http://papersubmission.scirp.org/ 